INTERNATIONAL JOURNAL OF SYSTEMATIC BACTERIOLOGY

Vol. 20, No. 4 October 1970

pp. $491-507$

Copyright 1970, Iowa State University Press

\title{
AMINO ACID SEQUENCE OF THE MUREIN AND TAXONOMY OF THE \\ GENERA LACTOBACILLUS, BIFIDOBACTERIUM, LEUCONOSTOC AND PEDIOCOCCUS
}

O. Kandler

Botanisches Institut der Universität München

\begin{abstract}
A survey of the distribution of the various murein (peptidoglycan) types within the lactobacilliand related organisms is given. While all the species of some groups (thermobacteria, pediococci) contain only one type of murein, the species of other groups (betabacteria, bifidobacteria, leuconostoc) contain several types. The most common type, which occurs at least in a few species of most of the groups, is the Lys-Asp in which the crosslinkage of the peptide subunits is mediated by asparaine.
\end{abstract}

Very early in cell wall research the amino acid composition of the murein (peptidoglycan, mucopolymer, mucopeptide) was supposed to be useful as a chemotaxonomic criterion at least within certain groups of bacteria (Cummins and Harris, 1956). During the past few years many more types of murein, than originally expected (Bhuysen, 1968; Schleifer, 1970), have been found. The determination of the qualitative or even the quantitative amino acid composition of the cell wall is no longer sufficient to characterize the type of murein unequivocally. As pointed out earlier (Kandler, 1967a) the amino acid content of 2 strains may be identical, but the amino acid sequence or even the type of cross linkage may be quite different.

Therefore, in all cases mentioned below, we have determined the amino acid sequence of the murein as described by Schleifer and Kandler (1967a) and Kandler et al. (1967). When the amino acid composition was identical with a murein $\bar{k}$ nown from previous studies, we prepared a partial acid hydrolysate and separated the peptides by two-dimensional paper chromatography. This "finger print" was compared with that of the strain investigated earlier.

When all spots were identical, we knew that the murein was of the same type as that of the strain studied before. If either the amino acid composition or the "finger print" was different from any known murein, the amino acid sequence was studied in detail.

The strains used were either isolated in our own laboratory, received from the ATCC, NCDO or from other laboratories. In all cases the most important criterions for the classification (Sugar fermentation, configuration of lactic acid etc.) were determined according to the methods described by Abo Elnaga and Kandler (1965). Unless otherwise stated, the species were characterized according to Bergeys Manual 7th Edition. In the following tables the ATCC or NCDO 
numbers are given if the strains investigated were supplied by these collections.

Table 1 shows all of the types of murein found in the organisms mentioned in this paper. The schemes represent typical fragments of the mureins. More or less frequently deviations from these schemes occur in the genuine murein, i.e.: not all of the $\mathbf{W}$-amino groups of the diamino acids are substituted and not all of the interpeptide bridges are actually cross linked. In addition, some of the muropeptides, which are not cross linked, have lost their terminal D-alanine, probably by the action of a carboxypeptidase. In the following description we shall use abbreviations for the various types of murein, using only the diamino acid and the interpeptide bridge as indicated in Table 1.

In many cases we have determined the composition of the teichoic acid as well. This cell wall component was extracted with trichloroacetic acid in the cold, precipitated by alcohol, hydrolysed and analysed by paper chromatography. The occurrence of glycerol was confirmed by enzymatic determination (Bergmeyer, 1962). Ester bound D-alanine was determined as alanine amide by incubating the cell walls with ammonia followed by paper chromatography. The structures of the various teichoic acids (Archibald et al. 1968) were not studied in detail.

\section{The genus Lactobacillus Beijerinck}

We follow the grouping of Orla Jensen (1919), using his genera as subgenera of Lactobacillus Beijerinck.

a) Thermobacterium Orla Jensen. As shown in Table 2, all the strains of the thermobacteria contain the L-Lys-D-Asp type of murein, as described in case of $\underline{L}$. Coryniformis by Plapp and Kandler (1967a). These strains also contain mostly teichoic acid of the glycerol type. Ester bound D-alanine could be detected in all cases in which teichoic acid was present. The only species which do not contain teichoic acid are $\underline{L}$. salivarius and $\underline{L}$. acidophilus. In the latter species, however, a few of the 35 strains tested contained small but significant amounts of teichoic acid.

b). Streptobacterium Orla Jensen and Sporolactobacillus Kitahara and Suzuki. The recently described species and subspecies $\underline{L}$. coryniformis, L. curvatus, L. casei ssp. pseudoplantarum, L. casei ssp. tolerans (Abo Elnaga und Kandler, 1965), L. casei ssp. fusiformis (Eschenbecher, 1969) and L. inulinus (Kitahara and Suzuki, 1963) were supplied by the authors. L. plantarum var. mobilis (Harrison and Hansen, 1959) was kindly sent to us by Dr. Hansen. Two other strains of motile lactobacilli were obtained from Dr. Sharpe (Reading). They also contain the meso-DAP-type of murein like Dr. Hansen's strain.

The subgenus Streptobacterium can be subdivided into two groups, based on the occurrence of the L-Lys-D-Asp and the meso-DAP-type of murein, as shown in Table 3. The meso-DAP-type of L. plantarum and $L$. inulinus was described in detail by Weiss et al. $(1967)$ and Matsuda et al. (1968a,b,).

Teichoic acid is very rare within this subgenus. With the exception of var. mobilis all strains of $L$. plantarum contain a ribitol type of teichoic acid. This type is well known from the cell walls of Bacilli. The other DAP containing species, L. inulinus and the motile strains are free of teichoic acid. A glycerol containing teichoic acid was found in large amounts in the cell walls of $\underline{L}$. casei ssp. tolerans. It was an unusual form, since no ester bound $\overline{D-a} \overline{\text { lanine }}$ could be found. 
a) meso-DAP-type:

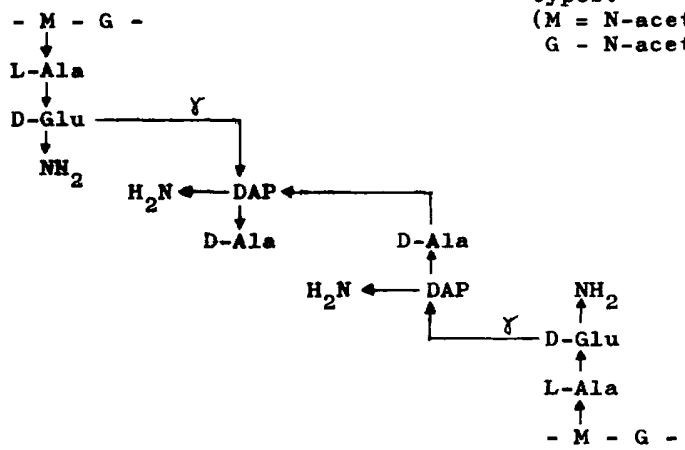

b) L-Lys (L-Orn) -D-Asp-type:

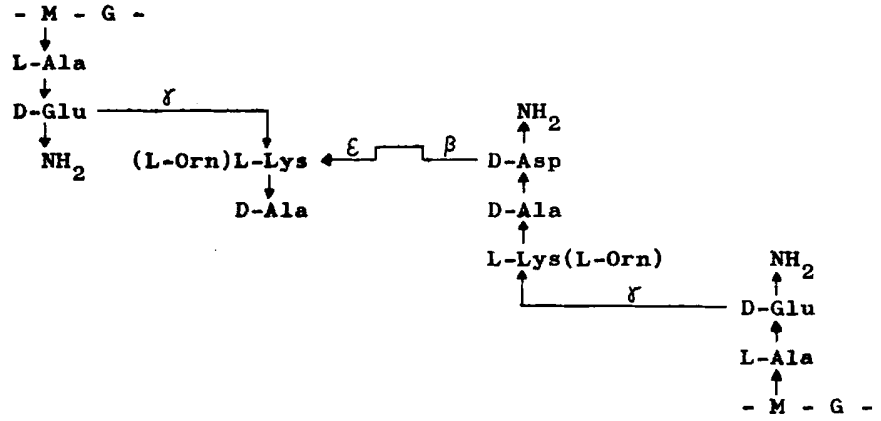

c) L-Lys-L-Ala $1-3^{-t y p e:}$

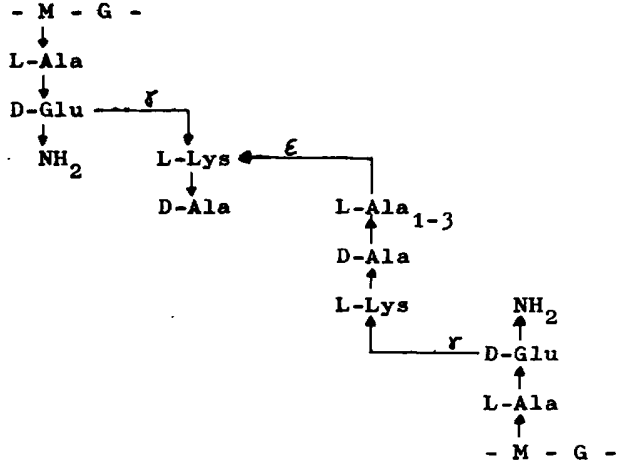


d) L-Lys-L-Sex-L-Ala ${ }_{2}$-type:

Table 1 continued

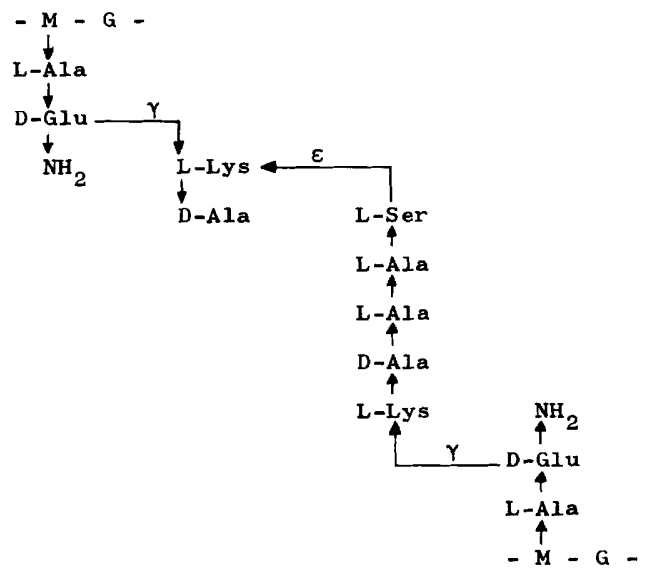

e) L-Lys-L-A Ia-L-Ser- and L-Lys-L-Ser-L-Ser-type:

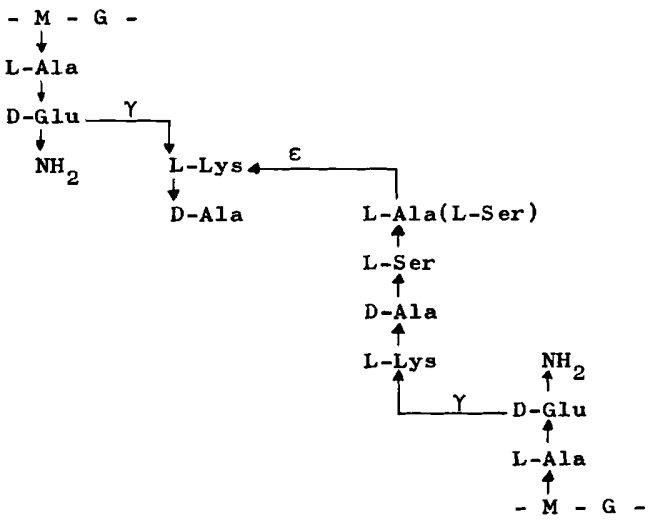

f) L-Lys-Gly-type:

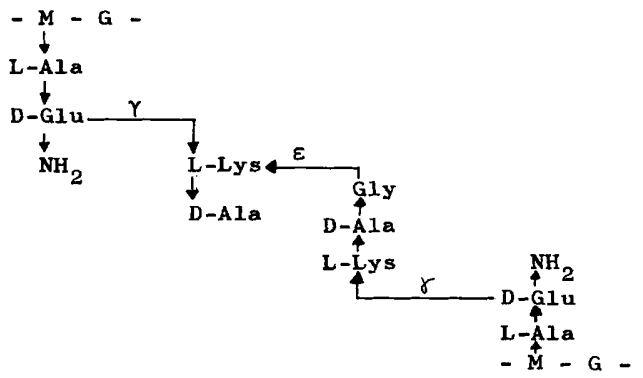


g) L-Orn-L-Ser-D-Asp-type :

Table 1 continued

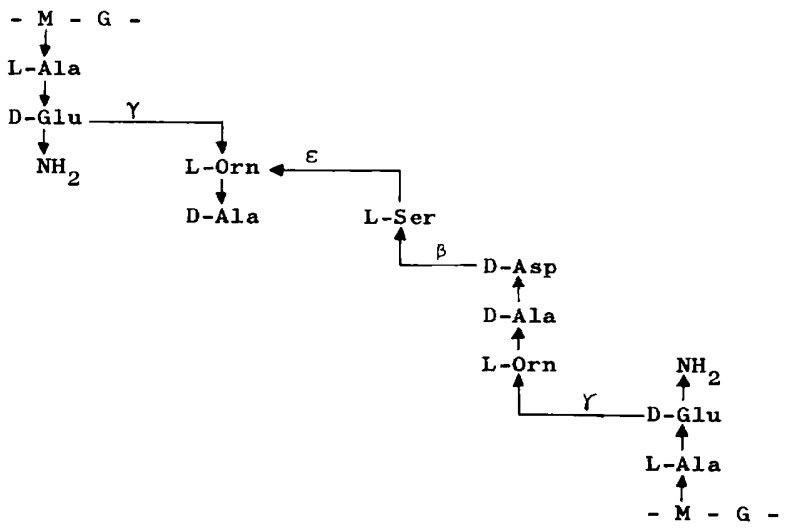

h) 0-Orn-L-Ser-L-Ala-Thr-L-Ala-type:

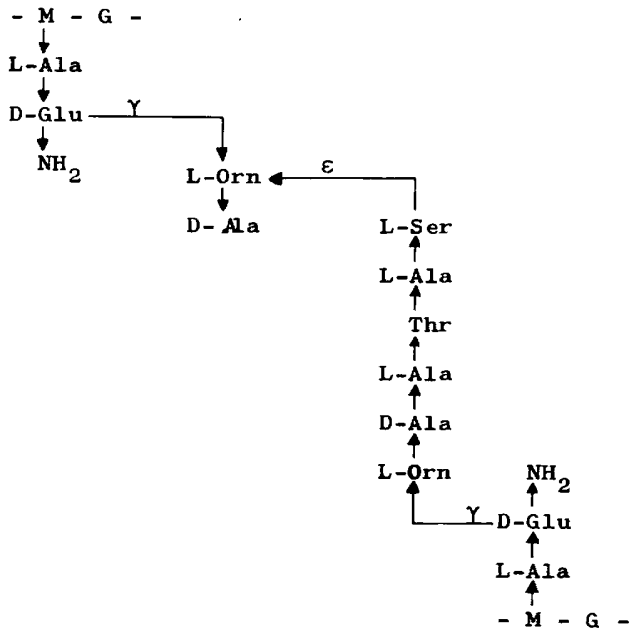


Table 2: Distribution of the murein types in the subgenus Thermobacterium

\begin{tabular}{|c|c|c|c|c|}
\hline Species & $\begin{array}{l}\text { Number } \\
\text { of } \\
\text { strains }\end{array}$ & $\begin{array}{c}\text { ATCC } \\
\text { numbers }\end{array}$ & Murein type & $\begin{array}{c}\text { Teichoic } \\
\text { acid }\end{array}$ \\
\hline L. bulgaricus & 6 & 11842 & L-Lys-D-Asp & glycerol \\
\hline L. helveticus & 4 & 15009 & " & $"$ \\
\hline L. Joghurti & 3 & $\begin{array}{r}521 \\
7993\end{array}$ & " & " \\
\hline L. lactis & 35 & 12315 & " & " \\
\hline L. acidophilus & 35 & 4356 & $"$ & no \\
\hline L. salivarius & 2 & 11741 & $"$ & $n$ \\
\hline L. delbrückii & 1 & 11978 & $"$ & glycerol \\
\hline L. leichmannii & 1 & 4797 & $"$ & $"$ \\
\hline
\end{tabular}

As pointed out earlier (Kandler, 1967b) it is tempting to exclude

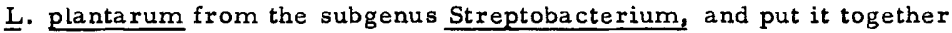
with $\underline{L}$. inulinus in a separate subgenus (Sporolactobacillus? ) which is characterized by showing some properties of the genus $B$ acillus, i.e. a DAP-type murein, ribitol teichoic acid, sometimes motility, nitrate reduction etc. This subgenus would be distinguished from the genus Bacillus by the absence of cytochromes. These organisms are therefore not able to carry out a true oxidative metabolism.

c. Betabacterium Orla Jensen. As shown in Table 4 the "classical" species of the subgenus Betabacterium contain the L-Lys-D-Asp type murein, while all of the recently described species show considerable variation of the interpeptide bridge. If teichoic acid is present, it is the glycerol type and contains ester-bound D-alanine.

L. cellobiosus is the only species within the whole genus, where lysine is replaced by ornithine (Plapp and Kandler, 1967a). Besides the two strains obtained from the ATCC, one strain from Dr. Reuter (Berlin) and one of our own isolated showed the same sugar fermentation pattern as the authentic strains of $\underline{L}$. cellobiosus and proved to contain L-ornithine, too. We feel therefore that the occurrence of ornithine is typical of this species. Experiments to replace ornithine by lysine by growing the organism in a medium containing I percent L- or D-lysine were not successful (unpublished data).

A more drastic change of the murein composition than in L. cellobiosus is found in the recently described species $L$. viridescens (Kandler et al. 1967) and L. coprophilus (Plapp and Kandler, 1967b; Holzapfel and Kandler, 1969). Here, D-aspartic acid is replaced by L-Ala-LAla-L-Ser, L-Ser-L-Ala, L-Ala-L-Ala or L-Ala. These 
Table 3: Distribution of murein types in the subgenera Streptobacterium and sporolactobacillus.

\begin{tabular}{|c|c|c|c|c|}
\hline Species & $\begin{array}{l}\text { Number } \\
\text { of } \\
\text { strains }\end{array}$ & $\begin{array}{c}\text { ATCC } \\
\text { numbers }\end{array}$ & Murein type & $\begin{array}{c}\text { Teichoic } \\
\text { acid }\end{array}$ \\
\hline $\begin{array}{l}\text { L. casei } \\
\text { ssp.casei }\end{array}$ & 10 & 393 & $L-L y s-D-A s p$ & no \\
\hline ssp.pseudoplantarum & 5 & - & " & $n$ \\
\hline ssp.rhamnosus & 2 & 7469 & $n$ & $t$ \\
\hline ssp.tolerans & 2 & - & $n$ & glycerol \\
\hline ssp.fusiformis & 3 & - & $"$ & no \\
\hline L. sake & 1 & 15521 & $"$ & $?$ \\
\hline $\begin{array}{l}\text { L. coryniformis } \\
\text { ssp.coryniformis }\end{array}$ & 4 & - & $"$ & no \\
\hline ssp.torquens & 2 & - & $n$ & $n$ \\
\hline L. curvatus & 4 & - & $"$ & $n$ \\
\hline $\begin{array}{l}\text { L. plantarum } \\
\text { ssp.plantarum }\end{array}$ & 80 & 8014 & meso-DAP-type & ribitol \\
\hline ssp.arabinosus & 40 & 10012 & $"$ & $"$ \\
\hline var. mobilis & 3 & - & $"$ & no \\
\hline L. inulinus & 1 & - & $"$ & $n$ \\
\hline
\end{tabular}

ting to note that the amino acid sequence of the interpeptide bridge of the one subspecies of $L$. viridescens (Syn. $L$. corynoides Kandler and Abo Elnaga, 1966) is inverse compared to the other. This confirms the grouping of the two forms within one species on the one hand, and their separation as a subspecies on the other hand. Actually, this classification was originally based on physiological and morphological evidences and only afterwards were the differences of the murein structure found.

The two subspecies of $L$. coprophilus are distinguished by the number of a lanine molecules within the interpeptide bridge and by the ability of one to form dextran (Holzapfel and Kandler, 1969). Even though the murein is more like that of Leuconostoc, they belong to the Betabacteria since they produce both isomers of lactic acid and are able to split arginine. While only one strain of the dextran forming 
Table 4: Distribution of murein types in the subgenus Betabacterium

\begin{tabular}{|c|c|c|c|c|}
\hline Species & $\begin{array}{c}\text { Number } \\
\text { of } \\
\text { strains }\end{array}$ & ATCC & Murein type & $\begin{array}{c}\text { Teichoic } \\
\text { acid }\end{array}$ \\
\hline L.fermenti & 6 & 14931 & $L-L y s-D-A s p$ & no \\
\hline L.brevis & 10 & 14869 & $n$ & glycerol \\
\hline L. buchneri & 1 & 4005 & "I & it \\
\hline L.fructovorans & 1 & 8288 & "I & no \\
\hline L.malefermentans & 1 & 11306 & "I & $?$ \\
\hline L.pastorianus & 1 & 8291 & $"$ & $?$ \\
\hline L.parvus & 1 & 11305 & " & $?$ \\
\hline L.frigidus & 1 & 11307 & $"$ & $?$ \\
\hline L.hilgardii & 1 & 8290 & $"$ & $?$ \\
\hline L.cellobiosus & 4 & $\begin{array}{l}11739 \\
11740\end{array}$ & L-Orn-D-Asp & no \\
\hline $\begin{array}{l}\text { L.viridescens } \\
\quad \text { ssp.viridescens }\end{array}$ & 6 & 12706 & $\mathrm{~L}-\mathrm{Lys}-\mathrm{L}-\mathrm{A} I \mathrm{a}-\mathrm{L}-\mathrm{S}$ er & $?$ \\
\hline ssp.minor & 4 & - & $L-L y s-L-S \operatorname{er}-(L-A 1 a)_{2}$ & glycerol \\
\hline $\begin{array}{l}\text { L. coprophilus } \\
\text { ssp.coprophilus }\end{array}$ & 3 & - & L-Lys-(L-Ala $)_{2}$ & no \\
\hline ssp.confusus & 14 & 10881 & L-Lys-L-Ala & 11 \\
\hline
\end{tabular}

subspecies $\underline{L}$. coprophilus ssp. confusus was known before (Holzapfel and Kandler, 1969), this organism was recently found to occur very frequently in fermenting vegetable juices (Stetter and Kandler, unpublished). All 15 strains isolated contain the same murein type.

Both subspecies of $\mathrm{L}$. coprophilus form short but slightly irregular rods, similar to $L$. viridescens $\mathrm{sp}$. minor. Therefore they can easily be confused with Leuconostoc, which very frequently shows elongated cocci, especially when freshly isolated. In fact, $\mathrm{ssp}$ confusus was originally considered to be a Leuconostoc (Johnson and McCleskey, 1957).

The rods of $L$. viridescens are also very irregular, but the rods of the other species mentioned in Table 4 are not. It seems that the change of the interpeptide bridge from D-aspartic acid to alanyl peptides parallels the irregular morphology.

d. Strains of unknown taxonomic position. Pette and van Beynum (1943) described the very peculiar species Lactobacillus bifermentans which forms not only lactate from glucose but ferments in addition lactate to acetic acid, alcohol, $\mathrm{CO}_{2}$ and $\mathrm{H}_{2}$. It is doubtful whether this species should be included in the genus Lactobacillus. it seems more reasonable to transfer it to a separate genus. 
The murein of two strains of $\underline{L}$. bifermentans which were obtained from Dr. Galesloot proved to be of the L-Lys-D-Asp-type. This may be taken as evidence for its relationship to the Lactobacillaceae.

Stadhouders et al. (1966) described recently several strains which cause spoilage of cheese by the production of gas from amino acids. These strains share many physiological criteria with the lactobacilli but do not ferment sugars. We studied 4 strains received from Dr. Galesloot (Ede) labelled L. I-7, Lb. I-17, Lb. 1-22 and Lb. 383 K6K. The murein of all strains was of the L-Lys-D-Asp-type. This finding supports the classification of these strains as lactobacilli although they certainly have to be grouped separately from all the other species in a new subgenus of Lactobacillus.

II. The Genus Leuconostoc Van Thieghem

The taxonomy of the genus Leuconostoc is still not very clear. We have followed mainly the newer descriptions of Garvie (1960, 1967a) and Whittenbury (1966). The main criteria, on which we have based the definition of species, are given in Table 5 together with the eype of murein found. A large majority of the strains contains the L-Lys L-Ser-(L-Ala $)_{2}$-type murein, while some strains do not contain serine but instead a dialanine as interpeptide bridge. By correlating the murein types with other physiological characters in order to group the strains into species, the situation was clear only in the case of $\underline{L}$. cremoris. All 8 strains available belong to the L-Lys-L-Ser-(L-A la $)_{2}$ type.

In the case of L.Lactis 3 out of 8 strains belonged to the L-Lys(L-Ala) $)_{2}$-type while the other strains contained the L-Lys-L-Ser(L-Ala $)_{2}$ type. It was not possible to find any other physiological character which showed the same distribution as the murein types.

Out of 7 strains of $\underline{L}$. paramesenteroides the type strain (NCDO 803) and one other strain belonged to the L-Lys-(L-Ala $)_{2}$-type, while the other 5 strains contained the L-Lys-L-Ser-(L-Ala) $)_{2}$-type. In addition the two groups differed with regard to the fermentation of arabinose and lactose. It was therefore suggested to separate the latter group as subspecies lactophilum from the subspecies paramesenteroides (Holzapfel and Kandler, 1970).

Within the 22 strains of $\underline{L}$. mesenteroides, 4 strains differed from the majority by their murein type. In addition the se 4 strains did not ferment melibiose and raffinose, while all the other 18 strains did ferment melibiose and most of them also raffinose. Based on the dif ference in the fermentation pattern and the murein type, we proposed the new subspecies amelibiosus (Holzapfel and Kandler, 1970).

The most unusual species is L. gracile (Muller-Thurgau) Bidan (1956) (syn. L. oenos Garvie). This species comprises only strains that have been isolated from wine. They are characterized by their ability to grow at low $\mathrm{pH}$, down to 4.2 , while growth at 6,5 , the usual optimum for the other species, is very poor or negligible.

The nomenclature of these strains is very confusing. Maller Thurgau and Osterwalder $(1913,1918)$ used the name Bacterium gracile for organisms isolated from wine. In 1936 Pederson reinves tigated one strain which he received from Dr. Osterwalder and suggested that this organism belonged to the genus Leuconostoc (Bergeys Manual 6th Edition 1948). A heterofermentative streptococcus isolated from wine were therefore called Leuconostoc gracile by Biden 


\begin{tabular}{|c|c|c|c|c|c|c|c|c|c|c|c|}
\hline \multirow[b]{2}{*}{ Species } & \multirow{2}{*}{ 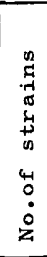 } & \multirow[b]{2}{*}{ 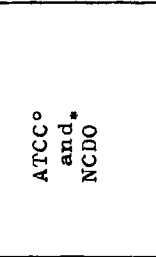 } & \multirow{2}{*}{ 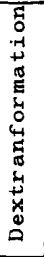 } & \multirow{2}{*}{ 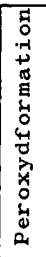 } & \multicolumn{6}{|c|}{ fermentation of } & \multirow[b]{2}{*}{ Murein type } \\
\hline & & & & & $\begin{array}{l}0 \\
0 \\
0 \\
0 \\
\stackrel{1}{1} \\
-71 \\
0 \\
0 \\
2 \\
4\end{array}$ & $\begin{array}{l} \\
0 \\
0 \\
0 \\
0 \\
0 \\
2 \\
x\end{array}$ & $\begin{array}{l}0 \\
0 \\
0 \\
0 \\
-1 \\
0 \\
0 \\
-1 \\
0 \\
0\end{array}$ & $\begin{array}{l}0 \\
0 \\
0 \\
0 \\
0 \\
0 \\
\pi \\
\\
+1\end{array}$ & $\begin{array}{l}0 \\
0 \\
0 \\
0 \\
4 \\
0 \\
5 \\
0\end{array}$ & $\begin{array}{l}0 \\
0 \\
0 \\
0 \\
-1 \\
0 \\
-1 \\
\overrightarrow{0} \\
\sum_{2}\end{array}$ & \\
\hline L.cremoris & 8 & $828^{*}$ & - & - & - & - & - & + & - & - & L-Lys-L-Ser-(L-Ala $)_{2}$ \\
\hline L.lactis & 8 & $546^{*} 533^{*}$ & - & + & - & - & - & + & + & + & L-Lys-L-Ser-(L-Ala $)_{2}+\mathrm{L}-\mathrm{Lys}-(\mathrm{L}-\mathrm{Ala})_{2}$ \\
\hline $\begin{array}{l}\text { L.paramesenteroides } \\
\text { ssp.paramesenteroides }\end{array}$ & 2 & $803^{*} 883^{*}$ & - & + & + & + & \pm & - & + & + & $\mathrm{L}-\mathrm{Lys}-(\mathrm{L}-\mathrm{Al} \mathrm{a})_{2}$ \\
\hline ssp.lactophilum & 5 & -- & - & + & - & + & + & + & + & - & $\mathrm{L}-\mathrm{Lys}-\mathrm{L}-\mathrm{Ser}-(\mathrm{L}-\mathrm{Ala})_{2}$ \\
\hline $\begin{array}{l}\text { L.gracile } \\
\text { (syn.L.oenos) }\end{array}$ & 23 & 1) & - & + & \pm & \pm & - & - & \pm & \pm & $\mathrm{L}-\mathrm{Lys}-\mathrm{L}-\mathrm{A} 1 \mathrm{a}-\mathrm{L}-\mathrm{Ser}+\mathrm{L}-\mathrm{Lys}-(\mathrm{L}-\mathrm{Ser})_{2}$ \\
\hline L.dextranicum & 1 & $517^{*}$ & + & - & - & - & - & - & + & + & $L-L$ ys-L-Ser- $(L-A l a)_{2}$ \\
\hline $\begin{array}{l}\text { L.mesenteroides } \\
\text { ssp.mesenteroides }\end{array}$ & 18 & 2) & + & - & + & + & + & - & + & + & L-Lys-L-Ser-(L-Ala ${ }_{2}$ \\
\hline ssp.amelibiosus & 4 & 3) & + & - & + & + & + & - & + & - & $L-L y s-(L-A 1 a)_{2}$ \\
\hline
\end{tabular}

1) $1668^{*}, 1669^{*} 1674^{*}, 1675^{*}, 1694^{*}, 1696^{*}, 1705^{*}, 1707^{*}, 1823^{*}, 1890^{*}, 1893^{*}$

2) $183^{\circ}, 523^{\circ}, 538^{\circ}, 8082^{\circ}, 8086^{\circ}, 8293^{\circ}, 8357^{\circ}, 8358^{\circ}, 8359^{\circ}, 9135^{\circ}, 10830^{\circ}, 10830 a^{\circ}, 10878^{\circ}, 12291^{\circ}$, $14430^{\circ}, 14935^{\circ}$.

3) $10882^{\circ}, 10883^{\circ}, 11449^{\circ}, 13146^{\circ}$. 
(1956). In 1965 some strains of cocci from wine were described by Nonomura et al. (1965) and grouped into 3 new species (L. lactosum, $\underline{L}$. infrequens and $\underline{L}$. vinarium). Later on Nonomura and Ohara (1967) transferred these species as subspecies to other species according to the classification used by Hucker and Pederson (1931) and created a further species, L. blayaisense. In 1967 Garvie (1967b) described some strains isolated from wine and called them L. oenos. We compared 23 strains of these organisms (Lauer et al., 1970), received from Dr. Garvie, Dr. Nonomura and Dr. Radler. They were identical with respect to their ability to grow at low $\mathrm{pH}$, to form peroxide and their inability to form dextran. They differed regarding their sugar fermentation pattern. All 23 strains investigated belong to the murein types L-Lys-L-Ala-L-Ser or Lys-(L-Ser) 2 , which were found before only in Lactobacillus viridescens ssp. viridescens (Kandler et al., 1967).

In most of the strains the majority of the interpeptide bridges are formed by the peptide L-Ser-L-Ala and the minority by L-Ser-L-Ser. In some strains the L-Ser-L-Ser bridges represent a significant percentage ( 20 to 50 percent) and in two strains they dominate with a presence of only a small percentage of L-Ser-L-Ala bridges. The quantitative variation of the two interpeptide bridges is reflected by the ratio serine/glutamic acid found in the total hydrolysate of the cell walls. When almost only L-Ser-L-Ala or L-Ser-L-Ser bridges are present the ratio is one or two, respectively. The mixture of both results in intermediary values.

To prove if the variation of the serine content is caused by the amino acid composition of the medium, we grew strains with a low and a high content of serine in media which were enriched by 0.5 percent alanine or serine. The ratio serine/glutamic acid of the cell walls changed only very little. This indicated that the ratio of both types of interpeptide bridges is a genetically determined property of the strains (Lauer et al. 1970).

The occurrence of the same murein type in all the strains isolated from wine supports their taxonomic separation from all the other strains of Leuconostoc. The question remains whether they should be regarded as only one species as supposed by Garvie (1967b) or placed in different species as done by Nonomura et al. (1965). We favor Garvie's suggestion to include all these strains in one species, regardless of their different fermentation pattern. According to the rule of priority the name L. gracile (Muller-Thurgau) Bidan must be chosen while $L$. oenos as well as the various names given by Nonomura et al. (1965) are synonyma.

\section{The genus Bifidobacterium Orta Jensen}

Most of the strains of Bifidobacterium investigated in this study were isolated from feces of infants and adults in our own laboratory. Some strains were obtained from Dr. Reuter (Berlin), Dr. Behrens (Lille) and from the ATCC. All strains isolated from the rumen of sheep, 6 strains from the feces of infants and one strain of Bacillus constellatus were obtained from Dr. Scardovi (Bologna).

The products of glucose fermentation of these strains were determined. Only those anaerobic strains forming acetic acid and lactic acid (about 3:2) but no $\mathrm{CO}_{2}$ were considered to be bifidobacteria. This type of fermentation was found to be typical of bifidobacteria by Scardovi 
and Trovatelli (1965) and De Vries et al. (1967). Usually the strains showed the well known irregular, branched rods, but some strains formed almost regular rods. Without knowing the fermentation pattern of the latter it would not be to know that they belong to Bifidobacterium.

To separate the strains into species we followed the classification given by Reuter (1964). The sugar fermentation patterns of all strains were determined with the exception of those obtained from Dr. Scardovi since they were sent to us as freeze dried powders.

As shown in Table 6 , the various murein types correlate very well with the species defined by Reuter. The well known strain L. bifidus var. pennsylvanicus ATCC 11863 as well as 5 other strains which had the: same fermentation pattern (․ - bifidum according to Reuter) contain the murein type L-Orn-L-Ser-D-Asp which had never before been found in any other organism. Its amino acid sequence has been described in detail by Koch et al. (1970a).

The recently described (Kandler et al.1968a) L-Lys-Gly-type was originally found in the so-called Bacillus constellatus. This organism, which was isolated from the intestine of bees, is a Bifidobacterium (Scardovi and Trovatelli, 1965). Such strains are now classified as B. asteriodes (Scardovi and Trovatelli, 1969). The same murein type was also found in 5 strains isolated from infants which were sent to us by Scardovi, in one strain each of $B$. infantis and $B$. breves received from Dr. Reuter and in 8 other strains of $\underline{B}$. infantis and $\underline{B}$. breve isolated in our laboratory from the feces of infants.

The most complex interpeptide bridge (L-Lys-L-Ser-L-Ala-Thr-LAla) described so far (Koch et al. 1970b) seems to be typical of $\underline{B}$. longum, a species which is isolated most frequently from the feces of adults. It was also found in a strain of $\underline{B}$. Lactentis isolated by Reuter from the feces of infants. Unfortunately we were not able to get other strains of this species. Therefore it remains uncertain, if this murein type is also common in B. lactentis.

The strains of $\underline{B}$. adolescentis, a species which is also very common in the feces of adults, contained either the L-Lys-Ser-L-Ala) 2 -type which is found in most strains of Leuconostoc or the L-Orn-(L-Lys)D-Asp-type which is similar to the murein of most lactobacilli. However, it differs from that of the lactobacilli, since L-ornithine and $\mathrm{L}-$ lysine are both present in varying amounts in the same murein. The ratio of Orn/Lys varies with different strains of $\underline{B}$. adolescentis, but is not influenced by the amount of lysine or ornithine in the medium.

The same varying ratio of Orn/Lys was found in the murein of 6 strains isolated from the rumen of sheep (Holzapfel et al., 1970). These strains were recently described as a new species $\underline{B}$. globosum by Scardovi et al. (1969). Here, the interpeptide bridge is formed by a trialanine, like in many streptococci and micrococci. In these genera, however, the diamine acid is lysine without any trace of ornithine.

Even though the number of strains investigated is still very limited, the data of Table 6 indicate that the murein type may be a valuable criterion for the separation of species or groups of species within the genus Bifidobacterium.

Recently the question was raised whether Bifidobacterium should be included in the Lactobacillaceae or in the Actinomycetaceae families. Unfortunately, the amino acid sequence of the murein of the latter group 
Table 6: Distribution of murein types in the genus Bifidobacterium

\begin{tabular}{|c|c|c|c|c|c|c|c|c|c|}
\hline \multirow[b]{2}{*}{ Species } & \multirow{2}{*}{ 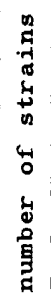 } & \multicolumn{7}{|c|}{ Acid from } & \multirow[b]{2}{*}{ Murein type } \\
\hline & & $\begin{array}{l}0 \\
0 \\
0 \\
0 \\
B \\
-1 \\
0 \\
0 \\
2 \\
<\end{array}$ & $\begin{array}{l}0 \\
0 \\
0 \\
-1 \\
\hat{x}\end{array}$ & 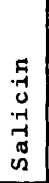 & 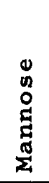 & 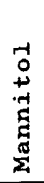 & 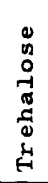 & $\begin{array}{l}0 \\
0 \\
0 \\
0 \\
-1 \\
0 \\
0 \\
0 \\
-1 \\
0 \\
0 \\
0\end{array}$ & \\
\hline B. bifidum & 6 & - & - & - & - & - & \pm & \pm & L-Orn-L-Ser-D-Asp \\
\hline B. infantis & 6 & - & - & + & + & - & + & + & L-Lys-Gly \\
\hline B. breve & 4 & - & - & + & + & + & + & + & $L-L y s-G 1 y$ \\
\hline B. lactentis & 1 & - & + & - & + & + & - & $(+)$ & L-Orn-L-S er -L-Ala-Thr-L-Ala \\
\hline B. adolescentis & 8 & + & + & + & - & \pm & + & + & $L-\operatorname{Orn}-(L-L y s)-D-A s p+L-L y s-L-S e r-(L-A l a)_{2}$ \\
\hline B. longum & 12 & + & + & - & \pm & - & \pm & - & L-Orn -L-Ser-L-Ala-Thr-L-Ala \\
\hline B. globosum & 6 & $\circ$ & $\circ$ & $\circ$ & $\circ$ & $\circ$ & o & $\circ$ & $L-O r n-(L-L y s)-(L-A l a)_{3}$ \\
\hline $\begin{array}{l}\text { B. asteroides } \\
\text { (Bacillus constellatus) }\end{array}$ & 1 & o & $\mathbf{0}$ & $\circ$ & o & $\mathbf{0}$ & $\circ$ & o & L-Lys-Gly \\
\hline
\end{tabular}


is not known yet. From the total amino acid composition of the cell walls known so far one can conclude that a variation of murein types similar to the genus Bifidobacterium occurs. There are also strains which contain lysine as well as ornithine. This would speak in favor of a relationship. On the other hand, there is obviously a tendency to vary the murein types within the betabacteria andLeuconostoc, too, and one may argue that the drastic variation within the bifidobacteria is just an evolutionary continuation of this tendency within the Lactobacillaceae.

The very similar mechanism of glucose fermentation of the heterofermenting lactobacilli and Bifidobacteria is another argument for a close relationship between the two genera. The fermentation pattern of the anaerobic actinomycetes is not clear at present but is certainly different from that of the bifidobacteria, although there might be some similarities. In general one gets the impression that the bifidobacteria hold a transient position between the heterofermenting lactobacilli and the actinomyces.

Therefore they may be grouped either way. I should prefer to consider them as genus of the Lactobacillaceae on the basis of the known biochemical similarities between both groups, whereas a possible relationship with the Actinomyceaceae remains to be studied more precisely.

\section{The genus Pediococcus}

From the well known species $\underline{P}$. cerevisiae we investigated the strains ATCC 8081,10791 as well as the strains ATCC 8042 and 12697 , which were named Leuconostoc by the ATCC but proved to be Pediococci according to their physiological properties. Six other strains of P. cerevisiae were isolated in our laboratory from various sources, while the strains of $\underline{P}$. acidilactici $(135,146)$ and of $\underline{P}$. pentosum (20, 183-w1) were received from Dr. Mundt. All strains contained the L-Lys-D-Asp- type murein. Since none of the Leuconostoc strains contained aspartic acid as a constituent of murein, the occurrence of aspartic acid in the cell wall hydrolysate can be used as an additional criterion to separate Pediococcus from Leuconostoc.

\section{Final Remarks}

A survey of the distribution of the murein types within the lactobacilli and related organisms is given in Fig. 1. The L-Lys-D-Asptype is obviously the most common. It is found only in the genera mentioned in this paper, the genus Streptococcus (Schleifer and Kandler, 1967b; Ghuysen et al., 1967; Kandler et al. 1968b), in some species of Actinomyces (Cummins and Harris, 1958; De Weese et al., 1968; Pine and Boone, 1967) and in Bacillus sphaericus Hungerer and Tipper, 1969; Ranfti et al., 1970).

While the Thermobacteria and the majority of the Streptobacteria. contain the L-Lys-D-Asp-type only, other groups show a more or less extensive variation which may indicate evolutionary trends. L. planta-

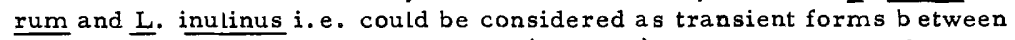
the lactobacilli and the sporeformers (Bacillus). Although most of the bacilli contain the meso-DAP-type, there is at least one species, B. sphaericus, which contains the L-Lys-D-Asp-type murein in the vegetative rod, while the spores contain the meso-DAP-type. Another spore 


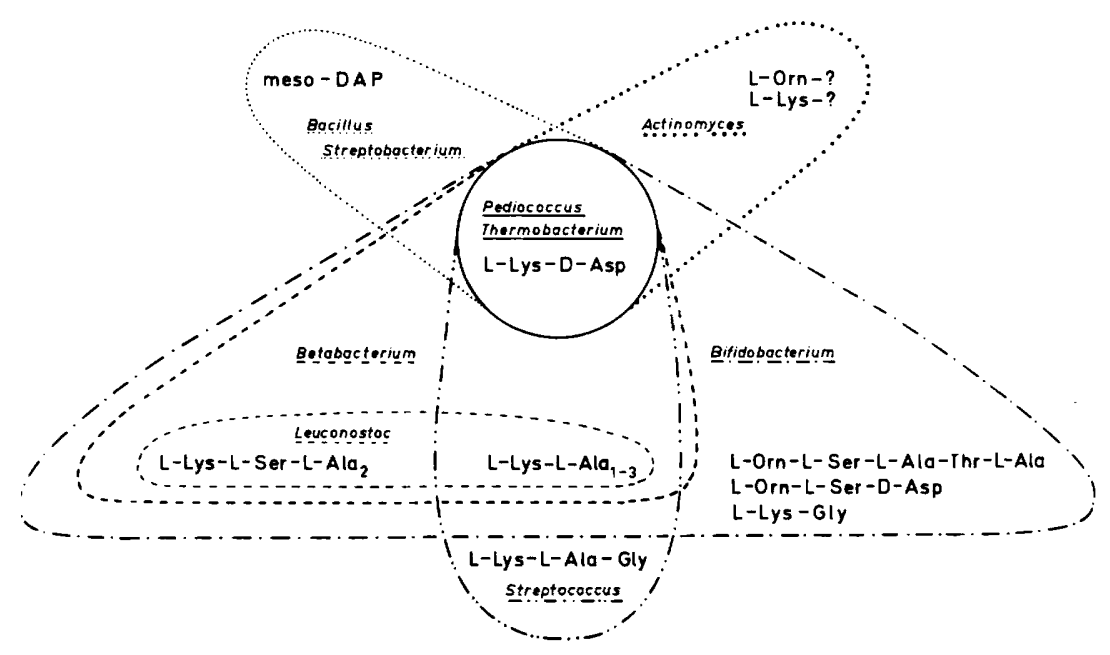

Figure 1. Survey of the murein types found in lactic acid bacteria and related organisms.

former which contains lysine and aspartic acid in the cell wall hydrolysate is $B$. pasteurii. The detailed study of the amino acid sequence by Ranftlet all. (1970) revealed that the murein does not belong to the LLys-D-Asp, as the qualitative analysis may suggest, but to the hitherto unknown L-Lys-L-Ala-D-Asp-type. This finding demonstrates again how necessary it is to study not merely the over all amino acid composition but the structure of the murein before the murein can be used as a taxonomic criterion.

Among the betabacteria the L-Lys-L-Ala, L-Lys-(L-Ala) 2 , L-LysL-Ala-L-Ser and L-Lys-L-Ser-(L-Ala) 2 containing species can be considered a missing link between the majority of the betabacteria and Leuconostoc. The latter genus has dropped the L-Lys-D-Asp-type completely.

The tendency to modify the murein which started within the betabacteria culminates within the bifidobacteria. They contain all types of murein found in the lactobacilli with the exception of the meso-DAPtype.

A similar variation may occur within the Actinomycetes. From the amino acid analysis known so far (Cummins and Harris, 1958; Pine and Boone, 1967) it seems very likely that some species contain the L-Lys-(L-Orn)-D-Asp-type, while other species certainly contain different types. Further studies on the structure of these mureins are necessary, before the question mark in Fig. I can be removed.

The L-Lys-D-Asp-type and the L-Lys-(L-Ala) 3 -types are dominating in the genus Streptococcus (Schleifer and Kandler, 1967a,b; Ghuysen et al., 1967; Kandler et al. 1968b). However, there are other types, such as the L-Lys-L-A La-Gly-type in Peptostreptococcus 
evolutus (Schleifer and Kandler, 1968) or the L-Lys-Thr-L-Ala-type in Streptococcus cremoris (Schleifer and Kandler, 1967b). Still other types might be present in some strains of $\underline{S}$. viridans and of the serological groups $\mathrm{O}, \mathrm{R}$ and $\mathrm{S}$ which we are presently studying. In general the murein types found in streptococci so far agree with the assumption of a close relationship to the other lactic acid bacteria.

Although the phylogenetic speculations may be disproved by further work, the murein type will be a useful criterion to separate species or groups of species from each other. Once the structure of the mureins are worked out, simplified methods of preparation and analysis of cell walls may be applied to use the murein composition as a tool even in routine classification.

\section{Acknowledgment}

The original work mentioned in this paper was supported by the Deutsche Forschungsgemeinschaft.

\section{Literature}

Abo Elnaga, J., and O. Kandler. 1965. Ztbl. Bakt. II. Abt. 119:1-36. Archibald, A. R., J. Baddiley and N. Blumson. 1968. Advances in Encymology 30:223-253.

Bergmeyer, H. U. 1962. Methoden der enzymatischen Analyse. Verlag Chemie Weinheim.

Bidan, P. 1956. Ann. Tech, agric, 5:597-615.

Cummins, C. S., and H. Harris. 1956. J. gen. Microbiol. 14: 583-600.

and - 1958. J. gen Microbiol. 18:173-189.

De Vries, W. S., J. Gerbrandy and A. H. Stouthamer. 1967. Biochem. Biophys. Acta 136:415-425.

De Weese, M. S., M. A. Gereneser and J. M. Slack. 1968. Appl. Microbiol. 16:1713-17.18.

Eschenbecher, F. 1969. Brauwissenschaften, 22:14-28.

Garvie, E. J. 1960. J. Dairy Res. 27:283-292. . 1967a. J. gen. Microbiol. 48:439-447.

$1967 \mathrm{~b}$. J. gen. Microbiol. $\overline{48}: 431-438$.

Ghuysen, J. M. 1968. Bact. Rev. 32:425-464.

E. Bricas, M. Leyh-Bouille, M. Lache and G. D. Shockman. 1967. Biochemistry $6: 2607-2619$.

Harrison, A. P., and P. A. Hansen. 1950. J. Bact. 59:444-446.

Holzapfel, W. and O. Kandker. 1969. Ztbl. Bakt. II. Abt. 123:637666.

and O. Kandler. 1970. Arch. Mikrobiol. (in press). V. Scardovi and O. Kandler. 1970. Zeitschr. Naturf. 24b, 1523-1528.

Hucker, G. J., and C. S. Pederson. 1931. Zbl. Bakt. II. Abt. 85: $65-114$.

Hungerer, K. D. and D. J. Tipper. 1969. Biochem. 8:3577-3587. Johnson, M. and L. S. McCleskey. 1957. J. Bact. 74:22-25. Kandler, O. 1967a. Ztbl. Bakt. I. Abt. Orig. 205:197-209. 1967b. Ztbl. Bakt. I. Abt. Suppl. 2:139-164. and Abo Elnaga. 1966. ZtbL. Bakt. II. Abt. 120:753-754. 
K. Plaff and W. Holzapfel. 1967. Biochim. Biophys. Acta. 147:257-261.

, D. Koch and K. H. Schleifer. 1968a. Arch Mikrobiol: $61: 161-186$.

, K. H. Schleifer and R. Dandl. 1968b. J. of Bact. 96 1935-1968b.

Kitahara, K. and J. Zuzuki. 1963. J. gen. Appl. Microbiol. 9 : $59-71$. $59-71$.

Koch, D., K. H. Schleifer and O. Kandler: 1970a.) Zeitsch (in press) 1970a).

(in press) ${ }^{\prime}$ and 1970b. Zeitschr. Naturf.

Lauer, E., W. Holzapfel and O. Kandler. 1970. Arch. Mikrobiol. (in press)

Matsuda, T., S. Kotani and K. Kato. 1968a. Biken J. 11:111-126. and . 1968b. Biken J. 11:127-138.

Muller-Thurgau, H. and A. Osterwalder. 1913. Zbl. bakt. II. Abt. 36:129-338.

, 1918. Zbl. bakt. II. Abt. 48:1-35.

Nonomura, H., T. Yamazaki and Y Ohara: Mitt. Klosterneuburg 15A: $242-254$.

and Y.Ohara. 1967. Mitt. Klosterneuburg 17A:449-465.

Orla Jensen, A. D. 1919. The lactic acid bacteria, Copenhagen, Andr. Fred. Host and Son.

Pette, J. W. and J. van Beyrum: Versl. Landbouw. K. Ondverz. 49: $313-321$.

Pine, L. and C. J. Boone. 1967. J. Bact. 94:875-883.

Plapp, R., and O. Kandler: 1967a. Zeitschr. Naturf. 22b:1062-1067. and - 1967b. Arch. Mikrobiol. 58:305-312.

$\overline{\text { Ranftl, H., K. H. Schleifer }}$ and O. Kandler. 1970. Arch. Mikrobiol. (in press).

Reuter, G. 1964, Ztbl. Bakt. I. Orig. 191:486-507.

Scardovi, V and L. D. Trovatelli. 1965. Ann. Microbiol. 15:19-25. and - 1969. Ztbl. Bakt. II. 123:64-88.

Mikrobiol. 68:278-295.

Schleifer, K. H. and O. Kandler. 1967a. Arch Mikrobiol. 57:335-364. and 1967b. Arch Mikrobiol. 57:365-381. 1970. Zbl. Bakt. I. Abt. Orig. 212:443-451. and O. Kandler, 1968b. Arch.f. Mikrobiol. 61:292-301.

$\overline{\text { Stadthouder }}$, J., T. E. Galesloot, H. T. Badings, H. A. Veringa and L. P. M. Langeveld. 1966. Nizo Nieuws $12 \mathrm{e}$, Ser. XI,

Weiss, N., R. Plapp and O. Kandler. 1967. Arch. Mikrobiol. 58: $313-323$.

Whittenbury, R. 1966. Arch. Mikrobiol. 53:317-327. 
